\title{
Desa Membangun: Analisis Perencanaan dan Penyusunan Anggaran Pendapatan dan Belanja Desa Tahun 2017
}

\section{Building Village: Planning and Arrangement Analysis Local Budget Village in 2017}

\author{
I Ketut Winaya* \& I Putu Dharmanu Yudartha** \\ Program Studi Ilmu Administrasi Negara, Fakultas Ilmu Sosial dan Ilmu Politik \\ Universitas Udayana, Indonesia
}

\begin{abstract}
Abstrak
Desa saat ini menjadi komponen penting dalam pembangunan nasional. Desa tidak lagi menjadi sasaran pembangunan tetapi menjadi subjek dari pembangunan tersebut. Melalui otonomi desa, pemerintah desa dituntut untuk mampu merespon problematika di desa dengan sebuah kebijakan atau program. Penelitian ini dilakukan dengan tujuan, pertama untuk mengetahui proses perencanaan dan penyusunan APBDes di beberapa desa tertinggal di Kecamatan Kintamani yaitu Desa Binyan, Mengani, Ulian, Langgahan, dan Abuan. Kedua, untuk menganalisis tantangan dan hambatan dalam perencanaan dan penyusunan APBDes. Ketiga, untuk menganalisis relevansi APBDes dengan arah tujuan pembangunan desa. Penelitian ini menggunakan metode kualitatif dengan pendekatan deskriptif dan pengumpulan data diperoleh dari dari hasil wawancara, dokumen serta studi kepustakaan. Hasil penelitian menunjukan bahwa dari sisi analisis struktur Anggaran Pendapatan Belanja Desa (APBDes) di beberapa Desa Kategori tertinggal di Kecamatan Kintamani Kabupaten Bangli belum mencerminkan Anggaran Pendapatan dan Belanja Desa (APBDes) yang berbasis kinerja yang dituangkan dalam kegiatan-kegiatan dengan keluaran dan hasil yang diharapkan. Efisiensi dalam pencapaian hasil dan keluaran yang disusun dengan pendekatan kinerja tersebut, mengutamakan outcome dan output. Prinsip-prinsip anggaran juga tidak dikesampingkan yakni transparansi, akuntabilitas anggaran, efisiensi, efektifitas anggaran, disiplin anggaran dan keadilan anggaran sesuai dengan salah satu asas yaitu value for money.
\end{abstract}

Kata Kunci: Otonomi Desa, Anggaran, Perencanaan, Penyusunan.

\begin{abstract}
This article was prepared in the background of the management of the Village Fund is not on target and its use is not yet optimal. This article is intended to analyze the impact of management and use of the Village Fund on regional development. Research method with qualitative approach. The results show; management and use of the Village Fund does not have a significant impact on the growth of regional development and the village development program is out of sync with the Regional development policy (RPJM Daerah). This impact is due to: a. The village has wide authority in determining its program plan, $b$. Areas lacking the authority to integrate development program policies. To integrate the synchronous village development program with the regional development policy, it is necessary to have the intervention authority of the Local Government regulation in order to direct the Village program to refer to regional development policy.

Keywords: Impact, Policy, Village Fund, Regional Development
\end{abstract}

How to Cite: Winaya, I.K. \& Yudartha, I.P.D. (2018). Desa Membangun: Analisis Perencanaan dan Penyusunan Anggaran Pendapatan dan Belanja Desa Tahun 2017. JPPUMA: Jurnal Ilmu Pemerintahan dan Sosial Politik UMA, 6 (1): 1-13

Corresponding author:

*E-mail : ketutwinaya14@yahoo.com ISSN 2549-1660 (Print)

**E-mail : p_dharmanu@unud.ac.id ISSN 2550-1305 (Online) 
I Ketut Winaya \& I Putu Dharmanu Yudartha, Desa Membangun: Analisis Perencanaan dan

\section{PENDAHULUAN}

Dinamika peran desa sebagai bagian integral pembangunan nasional serasa terpinggirkan. Desa hanya menjadi sebuah obyek pembangunan dibawah kontrol pemerintah pusat dan pemerintah daerah. Otonomi desa memberikan sebuah harapan dalam mengembalikan peran desa sebagai poros atau dasar pembangunan negara. Undang-undang no 5 tahun 2014 sebagai sebuah kebijakan atas tuntutan masyarakat desa beserta perangkat desa akan pemerataan kewenangan kepada desa dalam tata kelola pemerintahan di Indonesia. Desa diberikan kekuasaan dan kewenangan dalam mengatur rumah tangganya sendiri yang telah diatur dalam konstitusi serta memperoleh dana desa (grant) sesuai dengan luas wilayah dan kondisi masyarakat. Sebagai bentuk tanggung jawab kepada masyarakat desa maka aparat desa wajib menyusun anggaran pendapatan dan belanja desa (APBDes).

Otonomi desa dalam implementasinya mengalami tantangan dan hambatan, khususnya di Provinsi Bali. Bali memiliki keunikkan tersendiri dibandingkan dengan daerah lain di Indonesia karena mengenal dua jenis desa yaitu desa adat (pekraman) dan desa dinas. Dualisme desa adat (pakraman) dan desa dinas seharusnya mampu menjadi sebuah sinergitas dalam meningkatkan peran seluruh komponen pemerintahan desa dalam berkontribusi kepada masyarakat. Salah satu indikator dalam melihat hal tersebut adalah Anggaran Pendapatan dan Belanja Desa (APBDes). APBDes merupakan bentuk tangggung jawab pemerintahan desa kepada masyarakat melalui kebijakan-kebijakan yang dibiayai selama satu tahun anggaran. Hal ini yang dimaknai sebagai sebuah komitmen, seperti pendapat Kumorotomo (2013) bahwa anggaran harus punya keterkaitan langsung dengan kebijakan strategis. Prinsip-prinsip seperti money follows function (uang mengikuti fungsi) atau values for money (uang harus menghasilkan manfaat riil) menjadi bagian penting dalam perencanaan dan penyusunan APBDes. Kondisi tersebut menjadi tantangan dan masalah dalam implementasi khususnya di Provinsi Bali karena baru sedikit pemerintaan desa yang menyetor APBDes kepada pemerintah daerah (kabupaten/kota). Sejumlah desa dan program desa terkena imbas dari keterlambatan dalam menyetor APBDes (NusaBali, 21 Januari 2016). Banyak dari para aparat desa yang belum memahami atau mengatahui secara teknis cara dalam menyusun APBDes tersebut.

Bangli sebagai salah satu daerah tujuan wisatawan asing dan domestik di Bali seharusnya mampu mengatasi permasalahan khususnya kemiskinan. Hal menjadi sebuah indikasi ada permasalahan yang menarik untuk dikaji. Selain itu, permasalahan yang krusial lainnya yaitu terkait hasil kajian Bappenas yang menyatakan ada 6 desa tertinggal di Bali, dimana dari keenam desa itu ada 5 desa di kecamatan Kintamani Kabupaten Bangli. Satu desa tertinggal lainnya berada di Kabupaten Buleleng tepatnya di Desa Sepang Kelod, Kecamatan Busungbiu. 
Adapun lima desa tertinggal yang ada di Kecamatan Kintamani tersebut adalah Desa Binyan, Desa Mengani, Desa Ulian, Desa Langgahan dan Desa Abuan (Tribunnews, 2016)

Otonomi desa menjadi sebuah harapan dan tantangan bagi pemerintah desa serta masyarakat desa. Harapan dalam arti bahwa masyarakat desa dapat memberikan aspirasi dan kontrol terhadap birokrasi pemerintahan terdepadan yaitu pemerintahan desa. Nantinya, pemerintahan desa dapat merespon secara langsung apa yang telah diharapkan masyarakat desa. Di sisi lain, otonomi desa memberikan tantangan bagi pemerintahan desa dalam membuat kebijakan sesuai dengan anggaran yang dimiliki. APBDes harus menjadi sebuah cerminan harapan dan tuntutan masyarakat yang nantinya akan diwujudkan oleh pemerintah desa. Selain itu perencanaan dan penyusunan APBdes diharapkan mampu meningkat kualitas taraf hidup masyarakat desa sehingga tidak lagi masuk dalam kategori desa tertinggal.

Wildavsky dan Caiden dalam Wahab (2012) menyebutkan bahwa anggaran adalah suatu refleksi keuangan terhadap apa yang dilakukan oleh pemerintah atau apa yang hendak dilakukannya. Mandica (2001:5) mengatakan bahwa dalam perspektif desentralisasi, pemerintah daerah sebaiknya memainkan peran dalam penyusunan anggaran sebagai berikut:

1. Menetapkan prioritas anggaran berdasarkan kebutuhan penduduknya, bukan berdasarkan perintah penyeragaman dari pemerintah nasional;

2. Mengatur keuangan daerah termasuk pengaturan tingkat dan level pajak dan pengeluaran yang memenuhi standard kebutuhan publik di wilayahnya;

3. Menyediakan pelayanan dan servis pajak sebagaimana yang diinginkan oleh publik dan kepentingan daerah masing-masing;

4. Mempertimbangkan dengan seksama keuntungan sosial dari setiap program dan rencana pembangunan, bukan hanya kepentingan konstituen tertentu;

5. Menggunakan daya dan kekuatan secara independen dalam mewujudkan dan menstimulasikan konsep pembangunan ekonomi;

6. Memfokuskan agenda dan penetapan program ekonomi dalam anggaran yang mendukung kestabilan pertumbuhan dan penyediaan lapangan kerja di daerah;

7. Menentukan batas kenormalan pengeluaran sesuai dengan kebutuhan daerah;

8. Mencari dan menciptakan sumber-sumber pendapatan daerah sehingga mengurangi ketergantungan pada subsidi nasional.

Baswir (1998), mengemukakan bahwa penyusunan anggaran berdasarkan suatu struktur dan klasifikasi tertentu adalah suatu langkah penting untuk mendapatkan sistem penganggaran yang baik dan berfungsi sebagai pedoman bagi pemerintah dalam mengelola negara, sebagai alat pengawas bagi masyarakat terhadap kebijaksanaan dan kemampuan pemerintah. Penyusunan 
I Ketut Winaya \& I Putu Dharmanu Yudartha, Desa Membangun: Analisis Perencanaan dan

anggaran tidak bisa dilepaskan dari karakteristik suatu daerah, untuk dijadikan sebagai dasar pertimbangan dalam pengalokasian anggaran.

\section{METODE PENELITIAN}

Penelitian ini merupakan penelitian deskriptif dengan pendakatan kualitatif, penelitian deskriptif dimaksudkan untuk pengukuran yang cermat terhadap fenomena sosial tertentu (Singarimbun dan Effendi 1989). Peneliti melakukan analisis terhadap APBDes, mulai dari perencanaan, penyusunan hingga pengalokasian anggaran dalam pembangunann di desa. Penelitian ini dilakukan di salah satu desa di Kabupaten Bangli, penentuan daerah penelitian secara purposive. Daerah tersebut masuk kategori desa tertinggal di kecamatan Kintamani, Kabupaten Bangli, yaitu desa Binyan, mengani, Ulian, langgahan, dan Abuan Kintamani. Obyek penelitian ini adalah proses perencanaan dan penyusunan Anggaran Pendapatan dan Belanja sebagai bentuk komitmen pemerintah desa dalam pembangunan.

\section{HASIL DAN PEMBAHASAN}

\section{Konsep Good Governance di Desa}

Membahas tentang good governance sangatlah kompleks karena pandangan pandangan, kriteria dan makna mengenai good governance. Karena itu membangunan sebuah good governance dan dibawa dalam otonomi derah dan otonomi desa menjadi tantangan tersendiri. Perbedaan persepsi dalam membangun komitmen dan membuka partisipasi semua elemen-elemen di daerah menjadi hambatan belum lagi masalah kultur atau budaya masyarakat kita sebab good governance berkembang di negara maju yang belum tentu sesuai atau dapat diciptakan disini. Terlepas dari berbagai polemik yang ada mari kita melihat pandangan Garry Stocker (Fadillah, 2004) yang disebut sebagai penggagas pertama good governance. Dengan lima konsepnya tentang good governance yaitu: a) Pemanfaatan seperangkat institusi dan aktor baik dalam maupun luar pemerintahan; b) Menyatupadunya kekuatan pemerintah, sektor swasta dan masyarakat; c) Kesalingtergantungan antara ketiga kekuatan tersebut; d) Terbentuknya jaringan tersendiri antara ketiga kekuatan tersebut; f) Pemerintah cukup sebagai catalalic agent yang memberikan arahan, tidak perlu menjalankan sendiri.

Kelima konsep tersebut, dicoba untuk merefleksikan pelaksanaan otonomi daerah guna menciptaan good governance. Peran aktor-aktor pun coba disinergikan secara positif yaitu pemerintah, swasta dan masyarakat. Hubungan ketiga harus seimbang jangan sampai menimbulkan ketimpangan disatu sisi saja. Pemerintah daerah berperan membuka lingkungan politik yang kondusif dan hukum. Meningkatkan kepercayaan terhadap swasta dan masyarakat, karena swasta nantinya melakukan investasi dibidang tertentu untuk meningkatkan pendapatan daerah dan membuka lapngan kerja. Karena jelas pemerintah daerah tidak mampu 
membuka lapangan kerja karena kuota pegawai negeri yang terbatas. Swasta juga membantu meningkatkan perekonomian daerah sebagai bentuk investasi. Dan peran masyarakat membangun interaksi sosial politik, berpartisipasi pembangunan di daerah serta sebagai kontrol melalui wakil-wakil rakyat di legislatif.
Menerapkan good governance di tingkat desa bukan sesuatu yang mustahil dan menjadi sesuatu yang menarik dalam mendukung desa menjadi sentral pembangunan. Pemerintah desa menjadi governance desa yang mempunyai relasi dengan BPD, elemen-elemen masyarakat sipil, dan masyarakat ekonomi (Tabel 2.1).

Tabel 2.1 Peta Governance di Level Desa

\begin{tabular}{|c|c|c|c|}
\hline $\begin{array}{l}\text { Elemen } \\
\text { Governance }\end{array}$ & Aktor & Arena & Isu Relasional \\
\hline Negara & $\begin{array}{l}\text { Kepala desa } \\
\text { perangkat desa }\end{array}$ & $\begin{array}{lr}\text { Regulasi, } & \text { kontrol pada } \\
\text { masyarakat, } & \text { pengelolaan } \\
\text { kebijakan, } & \text { keuangan, } \\
\text { pelayanan. } & \end{array}$ & $\begin{array}{l}\text { Akuntabilitas, } \\
\text { transparansi, } \\
\text { responsivitas, } \\
\text { kapasitas }\end{array}$ \\
\hline $\begin{array}{l}\text { Masyarakat } \\
\text { politik }\end{array}$ & Badan Perwakilan Desa & $\begin{array}{lr}\text { Representasi, } & \text { artikulasi, } \\
\text { agregasi, } & \text { formulasi, } \\
\text { legislasi, sosialisasi, control }\end{array}$ & $\begin{array}{l}\text { Kapasitas, akuntabilitas, } \\
\text { dan responsivitas }\end{array}$ \\
\hline $\begin{array}{l}\text { Masyarakat } \\
\text { sipil }\end{array}$ & $\begin{array}{l}\text { Institusi sosial, } \\
\text { organisasi sosial, warga } \\
\text { masyarkat }\end{array}$ & $\begin{array}{l}\text { Keswadayaan, kerja sama, } \\
\text { gotong-royong, jaringan } \\
\text { social. }\end{array}$ & $\begin{array}{l}\text { Partisipasi (voice, access, } \\
\text { dan control) }\end{array}$ \\
\hline $\begin{array}{l}\text { Masyarakat } \\
\text { ekonomi }\end{array}$ & $\begin{array}{l}\text { Pelaku dan organisasi } \\
\text { ekonomi }\end{array}$ & Produksi dan distribusi & $\begin{array}{l}\text { Akses kebijakan } \\
\text { akuntabilitas social }\end{array}$ \\
\hline
\end{tabular}

Sumber: Dwipayana dan Eko (dalam Sidik, 2015)

Konsep governance di level desa banyak melibatkan komponen masyarakat terutama tokoh adat dan agama. Mewujudkan good governance di tingkat desa seperti hal di tingkat negara dan pemerintah daerah memerlukan sinergitas yang ideal dengan memposisikan pemerintah daerah sebagai sentral pembangunan multisektoral di desa.

\section{Konsep Desa}

Desa merupakan kesatuan masyarakat hukum (adat) yang memiliki otonomi asli dalam bentuk kewenangan untuk mengelola dan menyelenggarakan kehidupan sosialnya sendiri (Gunawan, 2013). Desa bagian integral dalam sebuah pemerintahan negara, jika dahulu lebih dikenal dengan pemerintahan kerajaan maka kondisi inilah yang menegaskan kembali bahwa diperlukan sebuah eksistensi keberadaan desa. Desa menjadi poros pembangunan seperti pada tabel 2.1, bahwa desa yang terdepan dalam mendukung pembangunan nasional sehingga pola pembangunan nasional bersifat bottom-up dimana desa diberikan peran yang signifikan. 
Tabel 2.2. Perbedaan Desa Lama dan Baru dalam Perspektif UU Desa

\begin{tabular}{|c|c|c|}
\hline & Desa Lama & Desa Baru \\
\hline Payung Hukum & $\begin{array}{l}\text { UU No. } 32 / 2004 \text { dan PP No. } \\
72 / 2005\end{array}$ & UU No. 6/2014 \\
\hline Asas Utama & Desentralisasi-risualitas & Rekognisi-subsidiaritas \\
\hline Kedudukan & $\begin{array}{l}\text { Sebagai } \\
\text { pemerintahan yang berada } \\
\text { dalam sistem pemerintahan } \\
\text { kabupaten/kota } \\
\text { government) }\end{array}$ & $\begin{array}{l}\text { Sebagai pemerintahan } \\
\text { masyarakat, hybrid antara self } \\
\text { govering community dan local } \\
\text { selfgovernment }\end{array}$ \\
\hline $\begin{array}{l}\text { Posisi dan } \\
\text { kabupaten.kota }\end{array}$ & $\begin{array}{l}\text { Kabupaten.kota mempunyai } \\
\text { kewenangan yang besar dan luas } \\
\text { dalam mengatur dan mengurus } \\
\text { desa }\end{array}$ & $\begin{array}{l}\text { Kabupaten/kota mempunyai } \\
\text { kewenangan yang terbatas dan } \\
\text { strategis dalam mengatur dan } \\
\text { mengurus desa: termasuk } \\
\text { mengatur dan mengurus bidang } \\
\text { urusan desa yang tidak perlu } \\
\text { ditangani langsung oleh pusat. }\end{array}$ \\
\hline $\begin{array}{lll}\begin{array}{l}\text { Delivery } \\
\text { program }\end{array} & \text { kewenangan } & \text { dan } \\
\end{array}$ & Target & Mandat \\
\hline Politik tempat & $\begin{array}{l}\text { Lokasi: Desa sebagai proyek dari } \\
\text { atas }\end{array}$ & $\begin{array}{l}\text { Arena: Desa sebagai arena bagi } \\
\text { orang desa } \\
\text { menyelenggarakan } \\
\text { pemerintahan, pembangunan, } \\
\text { pemberdayaan } \\
\text { kemasyarakatan }\end{array}$ \\
\hline Posisi dalam pembangunan & Obyek & Subyek \\
\hline Model Pembangunan & $\begin{array}{l}\text { Government driven development } \\
\text { atau community driven } \\
\text { development }\end{array}$ & Village driven development \\
\hline Pendekatan dan tindakan & Imposisi dan mutilasi sektoral & $\begin{array}{l}\text { Fasilitas, emansipasi } \\
\text { konsolidasi }\end{array}$ \\
\hline
\end{tabular}

Sumber: Desa Membangun Indonesia (2014)

\section{Otonomi Desa}

Widjaja (2003) menyatakan bahwa otonomi desa merupakan otonomi asli, bulat, dan utuh serta bukan merupakan pemberian dari pemerintah. Sebaliknya pemerintah berkewajiban menghormati otonomi asli yang dimiliki oleh desa tersebut. Sebagai kesatuan masyarakat hukum yang mempunyai susunan asli berdasarkan hak istimewa, desa dapat melakukan perbuatan hukum baik hukum publik maupun hukum perdata, memiliki kekayaan, harta benda serta dapat dituntut dan menuntut di muka pengadilan.

Dengan dimulai dikeluarkannya Undang-Undang Nomor 22 Tahun 1999 yang kemudian disempurnakan dengan dikeluarkannya Undang-Undang Nomor 32 Tahun 2004, selanjutnya diperbaharui lagi dengan Undang-undang Nomor 23 Tahun 2014 tentang Pemerintahan Daerah memberikan landasan kuat bagi desa dalam mewujudkan "Development Community" dimana desa tidak lagi sebagai level administrasi atau bawahan daerah tetapi sebaliknya sebagai "Independent Community" yaitu desa dan masyarakatnya berhak berbicara atas kepentingan masyarakat sendiri. Desa diberi kewenangan untuk mengatur desanya secara mandiri termasuk bidang sosial, politik dan ekonomi. Dengan adanya kemandirian ini diharapkan akan 
dapat meningkatkan partisipasi masyarakat desa dalam pembangunan sosial dan politik.

Pemerintah Desa merupakan salah satu lembaga yang ada dalam susunan kelembagaan pemerintahan Indonesia yang perlu dibangun dan diberdayakan. Karena desa berperan penting dalam setiap proses kebijakan serta menjadi penting dalam pemerataan pembangunan di Indonesia. Hal ini juga sejalan dengan konsep pembangunan pemerintah saat ini yang lebih berfokus pada konsep membangun Indonesia dari pinggiran maka salah satu yang dimaksud pinggiraan adalah Desa.

Anggaran Pendapatan dan Belanja Desa (APBDes) dalam menyusun rencana anggaran dilakukan dengan melibatkan partisipasi masyarakat dalam bentuk musywarah desa (musdes), sehingga tahapan penyusunan dan perencanaan para pengusul berkewajiban atau berhak ikut serta dalam musyawarah desa adalah masyarakat, dimana perencanaan pembangunan yang akan dilakukan merupakan kebijakan yang mendorong masyarakat (publik) dalam proses pengambilan keputusan, melalui usulanusulan oleh masyarakat itu sendiri dan yang berhak terlibat dalam proses musyawarah desa adalah seluruh komponen masyarakat desa seperti : Kepala Desa, Kepala Dusun, Perangkat desa, Badan Perwakilan Desa, Lembaga Permusyawaratan Desa, PKK desa, sekhaa Truna, Kelian Desa Pekraman dan Tokoh masyarakat.

Musyawarah tingkat desa dilaksanakan untuk menyatukan pandangan dan sinergitas dalam berbagai kepentingan dan kebutuhan masyarakat desa sehingga menjadi suatu usulan yang terpadu untuk diimplementasikan didalam penyusunan dan perencanaan anggaran pendapatan belanja desa sesuai dengan pos-pos anggaran yang mengedepankan skala prioritas pembangunan desa.

Tahapan pelaksanaan musyawarah desa dalam perencanaan dan penyusunan anggaran pendapatan belanja desa (APBDes) di beberapa desa tertinggal di Kecamatan Kintamani, Kabupaten Bangli adalah sebagai berikut: a) Mempresentasikan skala prioritas masalah desa seperti : kemiskinan, pembangunan infrastruktur jalan, pemberdayaan masyarakat dan pembangunan peningkatan sumberdaya manusia; b) Membahas pelaksanaan pembangunan desa tahun sebelumnya baik yang telah terealisasi dan atau yang belum terealisasi; c) Membahas skala prioritas pembangunan desa tahun yang akan datang dan pendanaannya sesuai dengan potensi dan permasalahan yang ada di desa.

Secara umum perencanaan dan penyusunan Anggaran Pendapatan Belanja Desa berjalan sesuai dengan keinginan atau kebutuhan masyarakat melalui mekanisme yang telah ditentukan di masing-masing desa tertinggal di Kecamatan Kintamani, Kabupaten Bangli.

\section{Desa Langgahan}

Desa langgahan merupakan salah satu desa yang tergolong tertinggal berdasarkan data Bappenas. Kondisi geografis desa langgahan lebih kepada daerah pertanian 
I Ketut Winaya \& I Putu Dharmanu Yudartha, Desa Membangun: Analisis Perencanaan dan

dimana lahan perkebunan mendominasi pertanian dengan luas lahan sebesar 300 hektar. APBDes Desa Langgahan mengalami defisit yaitu total belanja desa lebih tinggi dibandingkan pendapatan desa. Hal tersebut menjadi sebuah catatan dalam pengelolaan keuangan desa agar lebih efisien sesuai dengan salah satu asas yaitu value for money. Dari segi pendapatan desa memang alokasi yang terbesar tetap dari alokasi dana desa berdasarkan dana perimbangan Kabupaten Bangli. Penggunan belanja desa langgahan untuk belaja pegawai, kegiatan operasinal, tunjangan dan operasional BPD sebesar 27.18 persen dari total belanja APBDes tahun 2017, sedangkan sisanya sekitar 72.82 persen untuk bidang pembangunan, pembinaan dan pemberdayaan masyarakat di desa langgahan.

\section{Desa Abuan}

Kondisi geografis desa abuan hampir serupa dengan desa langgahan, dimana mayoritas lahan adalah lahan pertanian terutama perkebunan dan persawahan. Oleh karena itu, perlu melihat sejauh mana komitmen pemerintahan desa abuan dalam perencanaan dan penyusunan APBDes agar sesuai dengan potensi desa ABuan itu sendiri dan kebutuhan masyarakatnya. ada beberapa target belanja desa yang baru sebagian terealisasi. Kondisi tersebut memberikan beberapa indikasi yaitu belum memenuhi asas value for money khususnya pada indikator ekonomis yaitu tidak mampu mempergunakan seluruh anggaran yang diperoleh untuk kegiatan kepada masyarakat. Selanjutnya, prosentase alokasi anggaran untuk operasional desa sebesar 38.12 persen yaitu melebihi dari batas maksimum 30 persen dari aturan yang berlaku, sedangkan alokasi anggaran untuk bidang pembangunan, pembinaan dan pemberdayaan menjadi kurang dari 70\% yang juga lebih dari batas minimum alokasi yang telah ditentukan.

\section{Desa Binyan}

Sebagai salah satu desa tertinggal pada kabupaten Bangli, desa Binyan harus mampu merubah stigma tersebut dengan mempergunakan APBDes sesuai dengan kebutuhan dan tuntutan masyarakat. Oleh karena itu pada perencanaan dan penyusunan APBDes menjadi bagian penting sebagai komitmen pemerintahan desa dalam meningkatkan kualitas taraf hidup masyarakat desa. APBDes Desa Binyan mengalami defisit yaitu total belanja desa lebih tinggi dibandingkan pendapatan desa. Hal tersebut menjadi sebuah catatan dalam pengelolaan keuangan desa agar lebih efisien sesuai dengan salah satu asas yaitu value for money. ada beberapa kegiatan yang perlu dipertimbangkan terkait urgensinya kepada masyarakat desa Binyan seperti: pembangunan serta pemeliharaan yang tidak jelas untuk pembangunan seperti apa. Akan tetapi sebagai salah satu desa tertinggal, desa Binyan mempergunakan alokasi belanja desa dengan baik. Hal tersebut terlihat dari banyak kegiatan yang bersinggungan dengan masyarakat miskin seperti Polkesdes, Pembinaan LPM, penyuluhan sadar hukum dan pengutan kapasitas kelompok tani. 


\section{Desa Ulian}

Sebagai salah satu desa tertinggal pada kabupaten Bangli, desa Ulian harus mampu merubah stigma tersebut dengan mempergunakan APBDes sesuai dengan kebutuhan dan tuntutan masyarakat. APBDes Desa Ulian mengalami defisit yaitu total belanja desa lebih tinggi dibandingkan pendapatan desa. prosentase alokasi anggaran untuk operasional desa sebesar 26.04 persen yaitu dibawah dari batas maksimum 30 persen dari aturan yang berlaku, sedangkan alokasi anggaran untuk bidang pembangunan, pembinaan dan pemberdayaan sekitar 73.96\% yang berarti sudah sesuai dengan batas minimun yang telah ditentukan yaitu 70 $\%$. ada beberapa kegiatan yang perlu dipertimbangkan terkait urgensinya kepada masyarakat desa Ulian seperti: pembangunan serta pemeliharaan yang tidak jelas untuk pembangunan seperti apa. Akan tetapi sebagai salah satu desa tertinggal, desa Ulian mempergunakan alokasi belanja desa dengan baik. Hal tersebut terlihat dari banyak kegiatan yang bersinggungan dengan masyarakat miskin seperti sanitasi lingkungan, Pembinaan LPM, penyuluhan kelompok biina keluarga dan pengutan kapasitas kelompok tani.

\section{Desa Mengani}

Sebagai salah satu desa tertinggal pada kabupaten Bangli, desa Mengani harus mampu merubah stigma tersebut dengan mempergunakan APBDes sesuai dengan kebutuhan dan tuntutan masyarakat. APBDes Desa Mengani mengalami defisit yg cukup signifikan sekitar 141 juta rupiah yaitu total belanja desa lebih tinggi dibandingkan pendapatan desa. Hal tersebut menjadi sebuah catatan dalam pengelolaan keuangan desa agar lebih efisien sesuai dengan salah satu asas yaitu value for money. Dari segi pendapatan desa memang alokasi yang terbesar tetap dari alokasi dana desa berdasarkan dana perimbangan Kabupaten Bangli. Serta dana desa berdasarkan APBN yang diberikan ke masing-masing desa sesuai mandat Undang-undang no 6 Tahun 2014. Selanjutnya, prosentase alokasi anggaran untuk operasional desa sebesar 28.10 persen yaitu dibawah dari batas maksimum 30 persen dari aturan yang berlaku, sedangkan alokasi anggaran untuk bidang pembangunan, pembinaan dan pemberdayaan sekitar 71.90 $\%$ yang berarti sudah sesuai dengan batas minimun yang telah ditentukan yaitu $70 \%$. Selain itu, sisi positif dari APBDes tersebut lebih berimbang terutama antara pembinaan dan pemberdayaan dari segi alokasi anggaran. ada beberapa kegiatan yang perlu dipertimbangkan terkait urgensinya kepada masyarakat Desa Mengani seperti: pembangunan serta pemeliharaan yang tidak jelas untuk pembangunan seperti apa. Akan tetapi sebagai salah satu desa tertinggal, desa mengani mempergunakan alokasi belanja desa dengan baik. Hal tersebut terlihat dari banyak kegiatan yang bersinggungan dengan masyarakat miskin seperti sarana sanitasi lingkungan, poskesdes, pembangunan Bumdes dan penguatan kapasitas kelompok tani. Kondisi tersebut sangat berkaitan kebutuhan 
I Ketut Winaya \& I Putu Dharmanu Yudartha, Desa Membangun: Analisis Perencanaan dan

primer masyarakat di bidang kesehatan, kebersihan lingkungan, perekonomian lokal dan pengembangan kapasitas masyarakat khususnya petani.

Menurut peneliti sejalan dengan pendapat para pakar maka perencanaan dan penganggaran merupakan rangkaian kegiatan dalam satu kesatuan. Penyusunan rencana perlu memperhatikan kemampuan keuangan desa atau keuangan daerah yang tersedia. Sehingga dalam penerapannya, konsekuensi atas integrasi kegiatan perencanaan pembangunan dan penganggaran perlu diperhatikan. Perencanaan dan penganggaran merupakan proses yang terintegrasi oleh karenanya output dari perencanaan adalah penganggaran. Sehingga akan lebih bijak bila dalam proses musrenbang diberikan informasi mengenai kemampuan keuangan Pemerintah desa dimaksudkan agar masyarakat juga lebih bijak dalam memberikan usulan kegiatan pembangunan. Bila usulan kegiatan pembangunan dari masyarakat lebih mempertimbangkan kemampuan keuangan tentunya usulan akan lebih terarah dan pada gilirannya semakin memberikan peluang usulan kegiatan tersebut dapat diwujudkan pembangunannya. Keadaan ini tentunya akan menambah jumlah usulan masyarakat yang diformulasikan dalam APBDes sehingga pelaksanaan pembangunan yang memperhatikan kepentingan masyarakat semakin berpeluang untuk terwujud.

Peran dan partisipasi masyarakat dalam mekanisme perencanaan dan penyusunan Anggaran Pendapatan Belanja Desa (APBDes) di beberapa Desa kategori tertinggal di Kecamatan Kintamani Kabupaten Bangli kurang optimal karena meskipun dalam peraturan perundangan disebutkan bahwa masyarakat berhak memberikan masukan secara lisan atau tertulis dalam rangka penyiapan atau pembahasan perencanaan APBDes melalui musyawarah desa namun dari hasil penelitian menunjukkan partisipasi masyarakat masih sangat formalitas dan perhatian masyarakat terhadap perencanaan dan penyusunan APBDes masih sangat terbatas dan hanya menyerahkan mekanismenya terhadap orang yang ditokohkan. Penyusunan Anggaran Pendapatan Belanja Desa (APBDes) harus melibatkan semua komponen masyarakat karena unsur terpenting dari pembangunan desa adalah masyarakat itu sendiri yang langsung berdampak terhadap pembangunan desa sehingga peran dan aspirasi masyarakat sangat dibutuhkan oleh pemerintah desa sehingga program-program yang direncanakan kedalam APBDes berorientasi kepada kepentingan masyarakat. Dari sisi analisis struktur Anggaran Pendapatan Belanja Desa (APBDes) di beberapa Desa Kategori tertinggal di Kecamatan Kintamani Kabupaten Bangli dapat disimpulkan bahwa belum mencerminkan APBDes yang berbasis kinerja yang dituangkan dalam kegiatankegiatan dengan keluaran dan hasil yang diharapkan termasuk efisiensi dalam pencapaian hasil dan keluaran yang disusun dengan pendekatan kinerja mengutamakan outcome dan output dengan tidak 
menyampingkan prinsip-prinsip anggaran yakni transparansi, akuntabilitas anggaran, efisiensi, efektifitas anggaran, disiplin anggaran dan keadilan anggaran sesuai dengan salah satu asas yaitu value for money khususnya pada indikator ekonomis yaitu tidak mampu mempergunakan seluruh anggaran yang diperoleh untuk kegiatan kepada masyarakat.

\section{SIMPULAN}

Berdasarkan pembahasan dan untuk menjawab permasalahan yaitu bagaimana dampak pengelolaan dan penggunaan Dana Desa terhadap pembangunan daerah, maka dapat disimpulkan bahwa pengelolaan dan penggunaan Dana Desa tidak memberi dampak signifikan bagi pertumbuhan pembangunan daerah dan nyatanya program pembangunan Desa tidak sinkron dengan kebijakan pembangunan Daerah (RPJM Daerah). Dampak ini disebabkan Desa sebagaimana diatur berdasarkan UU No. 6 Tahun 2014 tentang Desa, memiliki kewenangan luas dalam menentukan rencana programnya sehingga daerah kesulitan mengintegrasikan kebijakan program pembangunan. Oleh karena itu, untuk mengintegrasikan program pembangunan Desa sinkron dengan kebijakan pembangunan Daerah diperlukan intervensi regulation Pemerintah Daerah guna mengarahkan program Desa mengacu pada kebijakan pembangunan Daerah.

\section{DAFTAR PUSTAKA}

Agusta, I. \& Fujiartanto. (2014). "Indeks Kemandirian Desa".Yayasan Pustaka Obor.Jakarta

Caiden, N. Aaron, W. (2012). "Dinamika Proses Politik Anggaran". Matapena, Yogyakarta

Eko, S. et.al. (2014). "Desa Membangun Indonesia". FPPD.Yogyakarta

Gunawan H, D. et..al. (2013). "Jalan Baru Otonomi Desa" Mengembalikan Otonomi Masyarakat. Kemitraan. Jakarta

Halim, A. \& Mujib, I. (2009), "Problem Desentralisasi dan Perimbangan Keuangan Pemerintahan Pusat-Daerah". Sekolah Pascasarjana UGM, Yogyakarta

Haris, S. (2007), "Desentralisasi dan Otonomi Daerah". LIPI Press, Jakarta

http://bali.tribunnews.com/2016/01/16/mahend ra-kaget-enam-desa-di-bangli-masuk-desatertinggal (diakses 5 Juli 2017)

http://www.balipost.com/news/2017/03/25/340 $3 /$ bangli-kabupaten-termiskin-ketiga-balikk-miskin-terbanyak-kecamatan.html diakses 5 Juli 2017)

Kumorotomo, W. (2008), Desentralisasi Fiskal, Kencana, Jakarta.

Kurniawan, B. (2015). "Desa Mandiri Desa Membangun". Kementrian Desa, Pembangunan Desa Tertinggal dan Trasmigrasi Republik Indonesia.Jakarta.,

Mardiasmo, (2004). Otonomi dan Manajemen Keuangan Daerah, Penerbit Andi.Yogyakarta.

Nazir, M. (2003). Metode Penelitian. Jakarta: Ghalia Indonesia.

Putra, F. (2004). “Kebijakan tidak untuk Publik".Resist Book.Yogyakarta

Sidik, F. (2015). "Menggali Potensi Lokal Mewujudkan Kemandirian Desa". JKAP.Yogyakar

Soetomo. (2013). "Strategi-strategi Pembangunan Masyarakat".Pustaka Pelajar.Yogyakarta

Sugiyono. (2000). "Metode Penelitian Administrasi”.Bandung: Alfabeta. (2008), "Metode penelitian Kuantitatif Kualitatif dan R\&D”. Bandung: Alfabeta.

UU No.6 Tahun 20014_Otonomi Desahttps://sulteng.antaranews.com/desa_ kalukubula_pengelola_dana_desa_terbaik $>[\overline{1}$ 1/04/2017]

https://kupastuntas.co/ labuhan_ ratu_baru_di_lampung_timur $>[11 / 04 / 2017]$

http://news.liputan6.com/read/2342666/kpkbanya-dana-desa-tidak-sesuaiperuntukkannya $>[10 / 17 / 2015]$

http://Liputan6.com>[03/10/2016]

https://suara.com/bisnis/pengelola dana_desa >[11/04/2017] 